J. Perinat. Med. 9 (1981) 235

\section{Does the administration of the calcium-antagonist verapamil in tocolysis with beta-sympathicomimetics still make sense?}

\author{
R. Strigl, U. Pfeiffer*, W. Erhardt*, P. Krieglsteiner, F. Fischbach, G. Blümel* \\ Gynecological Clinic (Comm. dir.: Prof. Dr. med. R. Thieme), \\ * Institute for Experimental Surgery (Head: Prof. Dr. med. Günther Blümel) of the \\ Technical University Munich, Germany
}

\section{Introduction}

Since the advent of medicamentous suppression of labor with beta-sympathicomimetics the calcium antagonist Verapamil ${ }^{* *}$ has been universally administered to antagonize cardiovascular and sub. jective side effects.

The administration of adrenergics induces an activation of the calcium-dependent electromechanical coupling in the myocardium (Fig. 1). The transmembranous calcium influx into the cell increases, resulting in enhanced activation of the ATP-ases. This, in turn, leads to increased consumption of high-energy phosphates, such as ATP and creatine phosphate. Due to the accelerated heart rate and increased tension, the myocardial oxygen consumption rises.

High doses of adrenergics but also protracted treatment with low doses, especially in conjunction with additional doses of Ca, vitamin D, AT 10 and cortisone as well as with potassium or magnesium deficiency or with heart disease may involve the risk of hypoxic necrosis development with the clinical picture of hypertrophic myocardiopathy [12].

In addition to general suppression of excitation, Verapamil antagonizes the increase of calcium influx and its consequences and thus lowers the myocardial oxygen requirement, resulting in an overall improvement of the energy balance.

\footnotetext{
** Verapamil - $\mathrm{HCl}$, active principle of Isoptin ${ }^{\circledR}, \mathrm{KNOLL}$
} AG Ludwigshafen/Rhein, FRG.

\section{Curriculum vitae}

RUDIGER STRIGL was born in 1944 in Seeon-Germany. He studied medicine at the Ludwig-MaximiliansUniversity in Munich, from which he was graduated in 1969. Since 1974 he is working in the Department of Obstetrics and Gynecology at the Technical Universtiy of Munich. Main field of interests: Perinatal medicine, especially tocolysis.

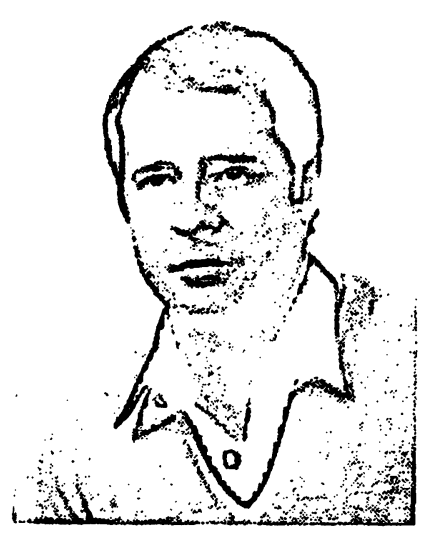

It is also hoped that this effect can be achieved in clinical tocolysis, in which Verapamil is administered in a maximum dose of $2 \mu \mathrm{g} / \mathrm{kg} / \mathrm{min}$.

A second effect, a peripheral vascular dilatation, is expected to lead to improved placental perfusion. Furthermore, amelioration of the subjective complaints associated with beta-mimetics is anticipated. These include tremors, heat sensations, tendency to break out in sweat, fear, and especially cardiac palpitations with their extremely unpleasant effect on the patient. The desired relaxation of the uteral muscles by the calcium antagonist, as demonstrated in vitro, could not be clinically objectified. The efficacy of Verapamil in doses of $2 \mu \mathrm{g} / \mathrm{kg} / \mathrm{min}$ as usual in tocolysis has not yet been established. In the numerous clinical studies only subjective 


\section{EFFECT OF ADRENERGICS AND}

CA-ANTAGONISTS ON THE MYOCARDIUM

(A. FLECKENSTEIN，J.JANKE， G.FLECKENSTEIN-GRON

1978)

ADRENERGICS

I

CA - INFLUX $\uparrow$

CA-ANTAGONIST

$\stackrel{\mathrm{I}}{\mathrm{I}}$

ACTIVITY OF ATP-ASE $\uparrow$

I

ATP + CP CONSUMPTION $\uparrow$

I

MECHANICAL ACTIVITY $\uparrow$

I

$0_{2}$ - CONSUMPTION $\uparrow$

(I)

\section{MYOCARDIOPATHY}

Fig. 1. Effect of adrenergics and Ca-antagonists on the myocardium.

sensations and inșensitive cardiovascular parameters of pregnant subjects could be monitored during tocolysis. A basic investigation of the desired calcium-antagonistic effect on the entire cardiovascular system including the pulmonary system is lacking.

In view of the increasing number of reports appearing in the past few years of cardiopulmonary complications, some fatal, we feel that a re-examination of the changes induced by betamimetics and their antagonization by means of the calciumantagonist Verapamil is urgent.

The objective of the present work is to investigate experimentally on dogs whether Verapamil in doses of $2 \mu \mathrm{g} / \mathrm{kg} / \mathrm{min}$ has an influence on the effects of beta-mimetics at all. The results will be evaluated in light of prior clinical experience.

\section{Material and methods}

Nine mongrel German shepherds with an average body weight of $31 \mathrm{~kg}$ were anesthetized with Fluanison and Fentanyl, corresponding to $0.15 \mathrm{mg} /$ kg Hypnorm ${ }^{\circledR}$, given intramuscularly, and Metomidate, corresponding to $0.33 \mathrm{ml} / \mathrm{kg}$ Hypnodil $^{\circledR}$, given intravenously. The anesthesia was continued by slow drip intravenous infusion of $0.15 \mathrm{ml} / \mathrm{kg} / \mathrm{h}$ Metomidate. The animals were relaxed with 0.1 $\mathrm{mg} / \mathrm{kg}$ Alcuroniumhydrochloride (Alloferin ${ }^{\circledR}$ ) given intravenously and subsequently with $0.1 \mathrm{mg} / \mathrm{kg} / \mathrm{h}$ by slow drip infusion. The controlled respiration was carried out with atmospheric air at constant volume, the minute respiratory volume being set at a $\mathrm{paCO}_{2}$ of $35 \pm 3 \mathrm{mmHg}$.

Following suitable preliminary measurements the animals were infused with Fenoterol* $(0.06 \mu \mathrm{g} /$ $\mathrm{kg} / \mathrm{min}$ ) and from the 30th minute with Fenoterol $(0.06 \mu \mathrm{g} / \mathrm{kg} / \mathrm{min})$ and Verapamil $(2 \mu \mathrm{g} / \mathrm{kg} / \mathrm{min})$ for a total of $90 \mathrm{~min}$.

A constant record was kept of the following parameters:

1. a) The pulmonary arterial pressure (PAP) and the pulmonary capillary wedge pressure (PCWP), which correlates to the left atrial pressure, by means of a $7 \mathrm{~F}$ Swan-Ganzthermal-dilution catheter located in the arteria pulmonalis.

b) The arterial pressure by means of a fiberoptical thermistor catheter, located in the aorta ascendens $\left(\mathbf{P}_{\text {AO }}\right)$.

2. From the measured pressure parameters and the cardiac output the total pulmonary vascular resistance (TPR) and the total systemic resistance (TSR) were derived.

3. The pressure ratios in the left ventricle were continuously monitored by means of an in: inserted microtip manometer and from the curves obtained cardiac inotropy quantities were calculated with the aid of a microprocessor. These included maximum rate of pressure increase $\left(\mathrm{dp} / \mathrm{dt}_{\max }\right)$, maximum acceleration of pressure increase $\left(\mathrm{d} 2 \mathrm{p} / \mathrm{dt}^{2}\right)$, intropy index of

* Partuisten ${ }^{\circledR}$, C. H. BOEHRINGER SOHN, Ingelheim/ Rhein, FRG. 
BRETSCHNEIDER (ING) and simultaneously total myocardial oxygen consumption $\left(\mathrm{E}_{\mathrm{T}}\right)$.

4. By taking blood samples the hemoglobin content $(\mathrm{Hb})$, oxygen partial pressure $\left(\mathrm{pO}_{2}\right)$, carbon dioxide partial pressure $\left(\mathrm{pCO}_{2}\right)$, sodium $\left(\mathrm{Na}^{+}\right)$, potassium $\left(\mathrm{K}^{+}\right)$and chloride $(\mathrm{Cl})$ concentrations, and the colloid osmotic pressure (COP) in the arterial and venous blood were determined.

5. To rule out ventilation disturbances, a continuous evaluation of oxygen consumption $\left(\mathrm{V}_{\mathrm{O}_{2}}\right)$ and carbon dioxide output $\left(\mathrm{V}_{\mathrm{CO}_{2}}\right)$ was made.

6. Thanks to the development of the thermal dye technique it is now possible to measure accurately the fluid spaces in the lungs on a continuous basis, i.e. the intravascular and extravascular spaces $[19,22,23,29]$.

As indicators indocyanine green and cold were used. Following an injection of ice-cold indocyanine solution into the right atrium, the timeconcentration curves recorded in the aorta ascendens after passage through the lungs revealed varying mean passage times, since the dye flowed only through the intravascular space, the cold, however, through both, the intravascular and the extravascular space. From the indicator dilution curves measured in the aortic arch, the cardiac output, the extravascular fluid volume in the lungs (EVV) and the total intravascular blood volume of the lungs (IVV) were calculated with a microprocessor.

The experimental setup described permitted a continuous appraisal of the functional parameters of the pulmonary and systemic hemodynamics, gas exchange, metabolic changes, and fluid displacement in the lungs. It enabled us to obtain a comprehensive picture of the pharmacologically induced physiological processes. Statistical valuation of the effect by the investigated drugs for all parameters was performed by calculating the Wilcoxontest for paired samples. Only variations compared to the base line were of interest. The level of significance was at $\alpha=0.05$. The figures show the mean value and the standard error of the mean respectively.

\section{Results}

Just shortly after infusion was commenced the following changes were observed:

The cardiac frequency increased with the administration of Fenoterol from $119 / \mathrm{min}$ to a maximum of $139 / \mathrm{min}(17 \%)$. The mean aortal pressure dropped from $83 \mathrm{mmHg}$ to a minimum of $56 \mathrm{mmHg}$, while the pressure amplitude increased (Fig. 2). The cardiac output rose from $116 \mathrm{ml} / \mathrm{kg}$ body weight/ $\mathrm{min}$ to a maximum of $158 \mathrm{ml} / \mathrm{kg}$ body weight $/ \mathrm{min}$. The total systemic resistance (TSR) decreased by a maximum of $44 \%$ (Fig. 3).

The changes are significant $(\mathrm{p}<0.05)$.

After administration of Verapamil only the aortal pressure continued to decrease further. The other parameters did not change significantly.

HEART RATE

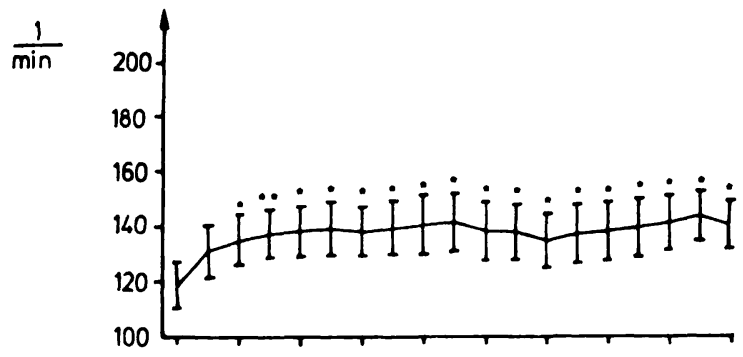

MEAN AORTAL PRESSURE

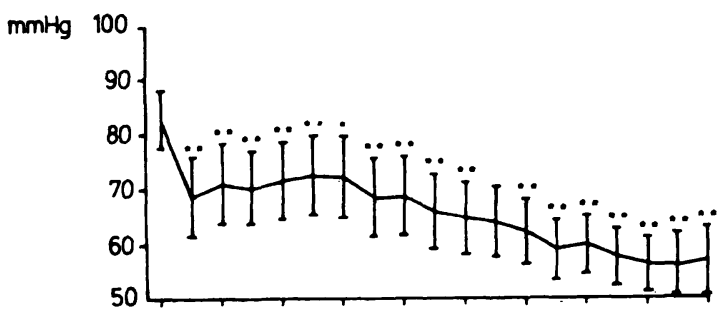

SYSTOLIC AORTAL PRESSURE - .. -

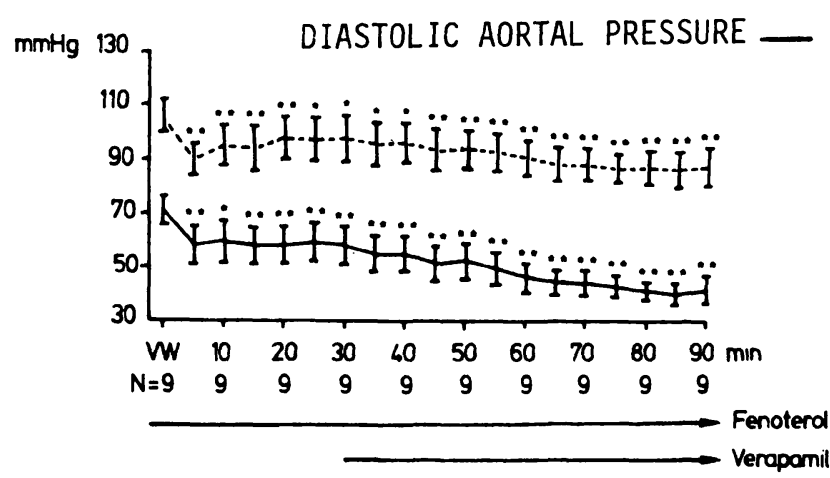

Fig. 2. Changes in heart rate and aortal pressure in dogs after administration of Fenoterol $(0.06 \mu \mathrm{g} / \mathrm{kg} / \mathrm{min})$ and subsequently of Verapamil $(2 \mu \mathrm{g} / \mathrm{kg} / \mathrm{min}) ;^{*}=p<0.05$, $* *=\mathrm{p}<0.01$. 

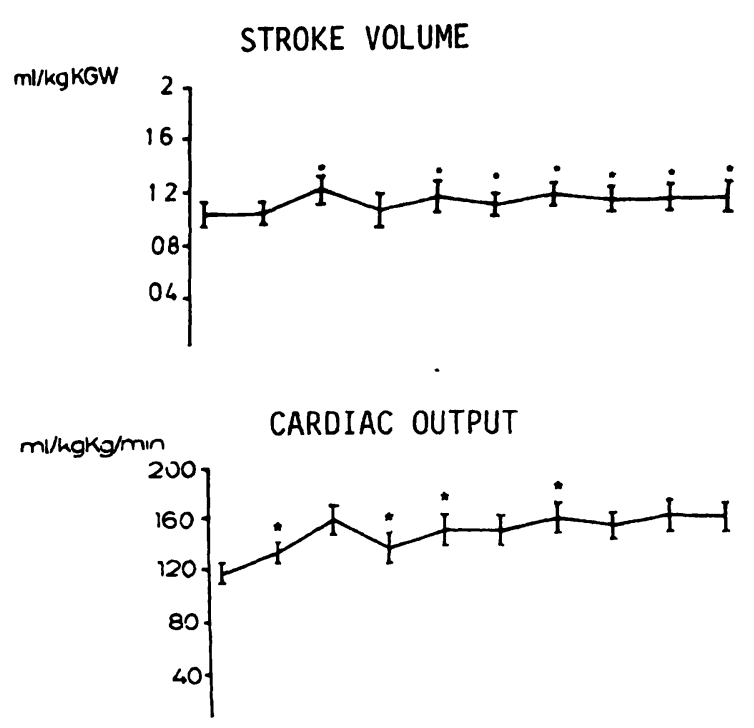

TOTAL SYSTEMIC RESISTANCE _ _ - :

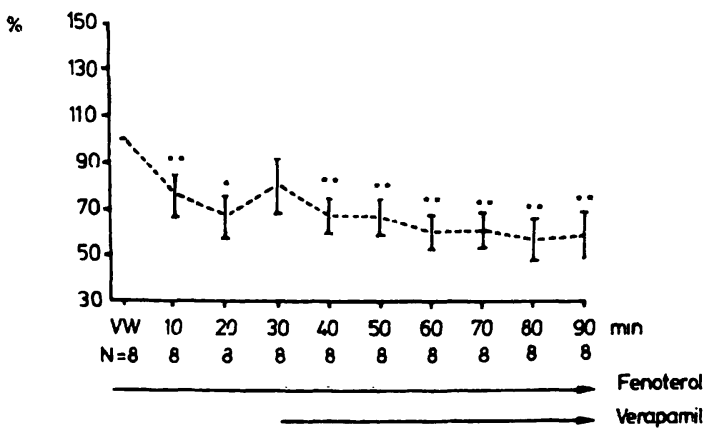

Fig. 3. Stroke volume, cardiac output and total systemic resistance in dogs after administration of Fenoterol $(0.06$ $\mu \mathrm{g} / \mathrm{kg} / \mathrm{min})$ and subsequently of Verapamil $(2 \mu \mathrm{g} / \mathrm{kg} / \mathrm{min})$; $*=\mathrm{p}<0.05, * *=\mathrm{p}<0.01$.

The quantities measured in the left ventricle also demonstrated beta-adrenergic-induced changes:

The maximum rate of pressure increase rose with the administration of Fenoterol alone by a maximum of $34 \%$ and the maximum acceleration of pressure increase by a maximum of $58 \%$. The inotropy index after BRETSCHNEIDER increased by a maximum of $67 \%$ (Fig. 4). The total myocardial oxygen consumption $\left(\mathrm{E}_{\mathrm{T}}\right)$ increased similarly after administration of the beta-sympathicomimetic by a maximum of $25 \%$ (Fig. 5). These changes were also significant and were in no way meaningfully influenced by the addition of Verapamil.

The mean pulmonary arterial pressure increased under the influence of Fenoterol from 15.9 to $\mathrm{dp} / \mathrm{dt}_{\max }$ :MAXIMUM RATE OF PRESSURE INCREASE $\mathrm{mmH} / \mathrm{s}$

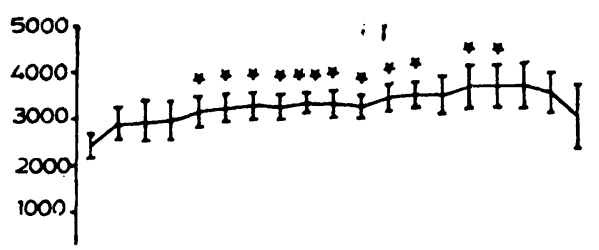

$\mathrm{d} 2 \mathrm{p} / \mathrm{dt}^{2}$ : maximum acceleration of pressure increase $\mathrm{mmHg} / \mathrm{sec}^{2}$

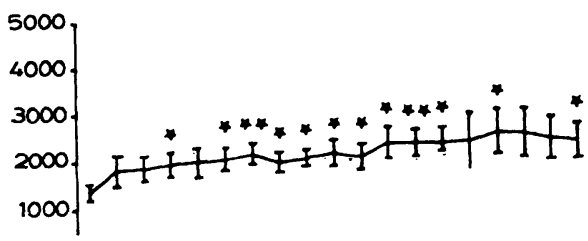

ING: INOTROPY INDEX AFTER BRETSCHNEIDER $\mathrm{mO}_{2} \mathrm{sec} 100$

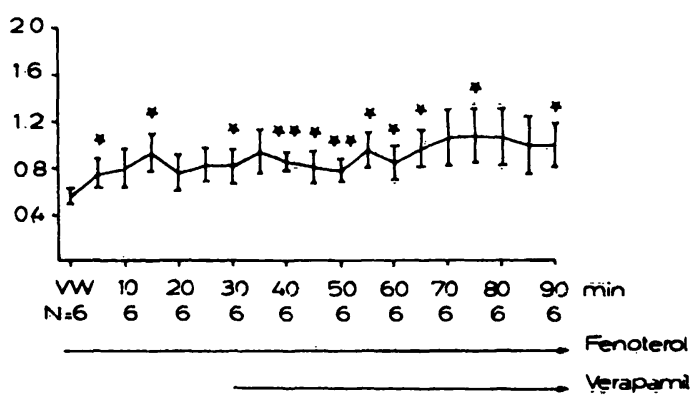

Fig. 4. Behaviour of the inotropy parameters in dogs after administration of Fenoterol $(0.06 \mu \mathrm{g} / \mathrm{kg} / \mathrm{min})$ and subsequently of Verapamil $(2 \mu \mathrm{g} / \mathrm{kg} / \mathrm{min}) ; *=\mathrm{p}<0.05$, $* *=\mathrm{p}<0.01$.

$18.3(15 \%)$ and reached a maximum of $19.9 \mathrm{mmHg}$ with the administration of Fenoterol + Verapamil. By contrast, the pulmonary capillary wedge pressure remained constant at $8.61 \mathrm{mmHg}$ throughout the entire experiment. The slight increase in total pulmonary resistance was not significant (Fig. 6). The extravascular fluid volume in the lungs increased after just 20 minutes form $8.9 \mathrm{ml} / \mathrm{kg}$ body weight to $12.7 \mathrm{ml} / \mathrm{kg}$ body weight $(42 \%)$. The fluid displacement shifted in favour of the interstice. In accordance with these findings the intravascular fluid volume decreased (Fig. 7a). The total fluid volume remained unchanged throughout the experiment at an average of $22.5 \mathrm{ml} / \mathrm{kg}$ body weight (Fig. 7b). Here too, the administration of Verapamil brought no significant further changes. 


\section{'ETOTAL : TOTAL OXYGEN CONSUMPTION OF \\ THE LEFT VENTRICLE IN DOGS}

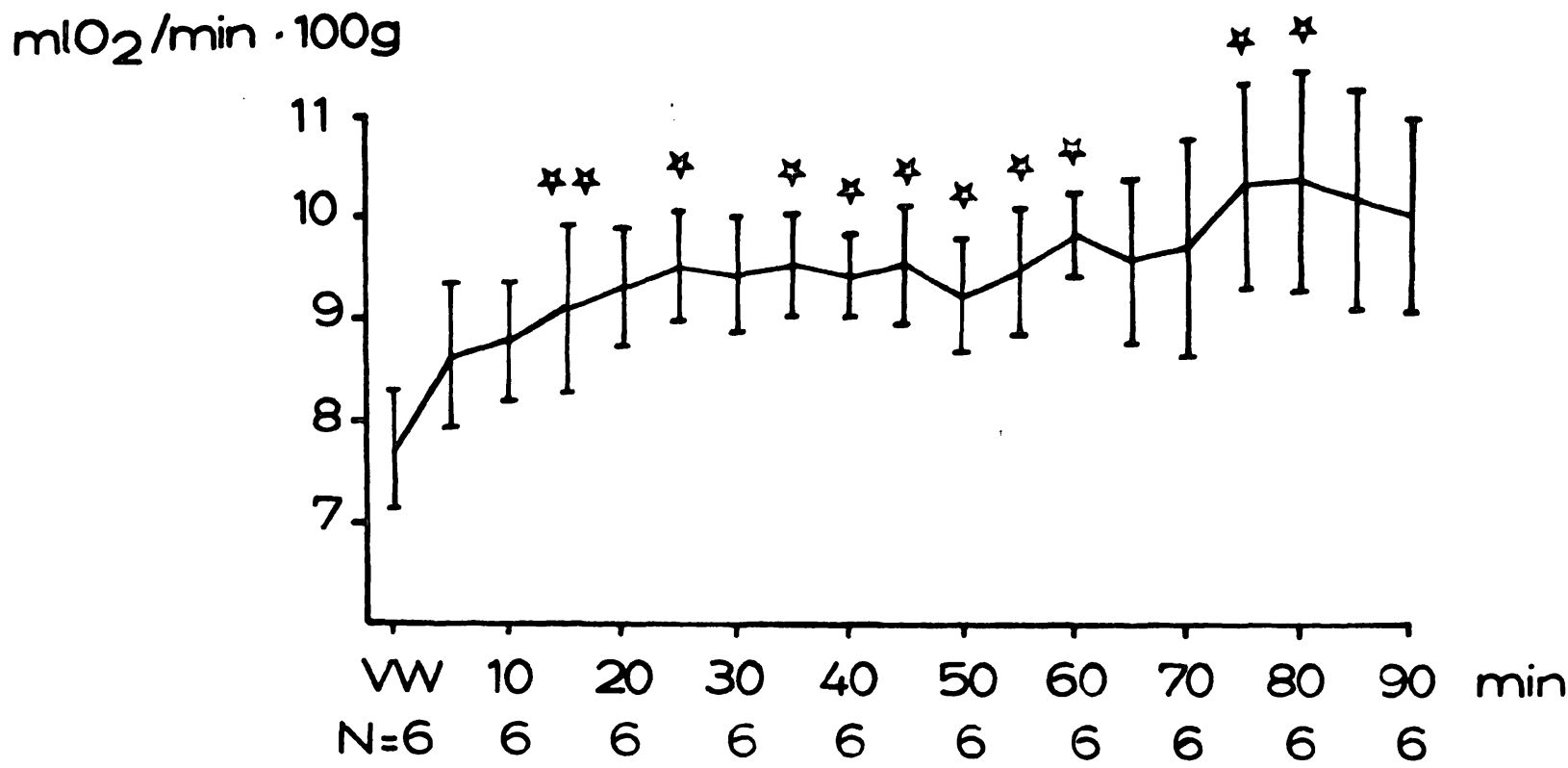

Fenoterol

Verapamil

Fig. 5. Total oxygen consumption of the left ventricle in dogs after administration of Fenoterol $(0.06 \mu \mathrm{g} / \mathrm{kg} / \mathrm{min})$ and subsequently of Verapamil $(2 \mu \mathrm{g} / \mathrm{kg} / \mathrm{min}) ; *=\mathrm{p}<0.05, * *=\mathrm{p}<0.01$.

The arterial blood gas analyses showed a drop in the oxygen partial pressure form $84.3 \mathrm{mmHg}$ to $80.9 \mathrm{mmHg}$ and in the oxygen saturation from $92.7 \%$ to $87.8 \%$, as well as an increase in the $\mathrm{CO}_{2}$ partial pressure from $37.7 \mathrm{mmHg}$ to a maximum of $47.5 \mathrm{mmHg}$ (Fig. 8).

In addition, a highly significant drop in the arterial $\mathrm{pH}$ from 7.42 to 7.25 , in the standard bicarbonate from $23.4 \mathrm{mval} / 1$ to $19.1 \mathrm{mval} / \mathrm{l}$, and in the base excess from $+0.2 \mathrm{mval} / 1$ to $-7 \mathrm{mval} / 1$ was observed (Fig. 9).

The changes in the venous system were even more pronounced. Here the $\mathrm{pH}$ showed a highly significant drop from 7.4 to 7.18, the $\mathrm{HCO}_{3}^{-}$from 27.0 $\mathrm{mval} / 1$ to $20.1 \mathrm{mval} / 1$, and the base excess from $+2.8 \mathrm{mval} / 1$ to $-7.5 \mathrm{mval} / 1$ (Fig. 10).

The venous blood gases analyses revealed a strong increase in the $\mathrm{O}_{2}$ partial pressure from $38.8 \mathrm{mmHg}$ to $57.3 \mathrm{mmHg}$ and in the venous $\mathrm{CO}_{2}$ partial pressure from $45.2 \mathrm{mmHg}$ to $58.1 \mathrm{mmHg}$ (Fig. 11).
The oxygen absorption increased at constant respiratory volume and constant respiratory rate from $159 \mathrm{ml} / \mathrm{min}$ to $183 \mathrm{ml} / \mathrm{min}(15 \%)$.

The $\mathrm{CO}_{2}$ output increased even more strongly from $116 \mathrm{ml} / \mathrm{min}$ to $144 \mathrm{ml} / \mathrm{min}(24 \%)$ with a consequent increase of the respiratory quotient (RQ) from a physiological value of 0.75 to 0.83 (Fig. 12). The other changes in the above parameters after the administration of Verapamil were not significant.

The colloid osmotic pressure in the plasma remained constant at a mean value of $18.4 \mathrm{mmHg}$. The serum potassium decreased only negligibly from $3.22 \mathrm{mval} / \mathrm{l}$ to $2.65 \mathrm{mval} / \mathrm{l}$, whereas the serum sodium remained unchanged at about 148 mval/l (Fig. 13).

With exception of the aortal pressure, which continued to drop after administration of Verapamil, none of the measured parameters was significantly further influenced by the calcium-antagonist Vera- 
MEAN PULMONARY ARTERIAL PRESSURE

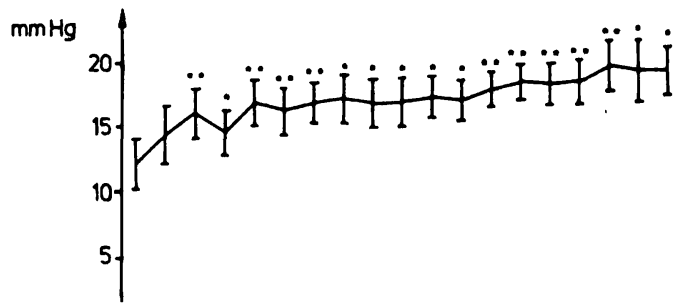

PULMONARY CAPILLARY WEDGE PRESSURE

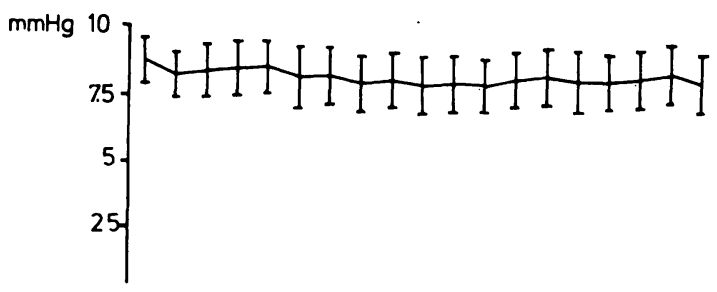

TOTAL PULMONARY VASCULAR RESISTANCE

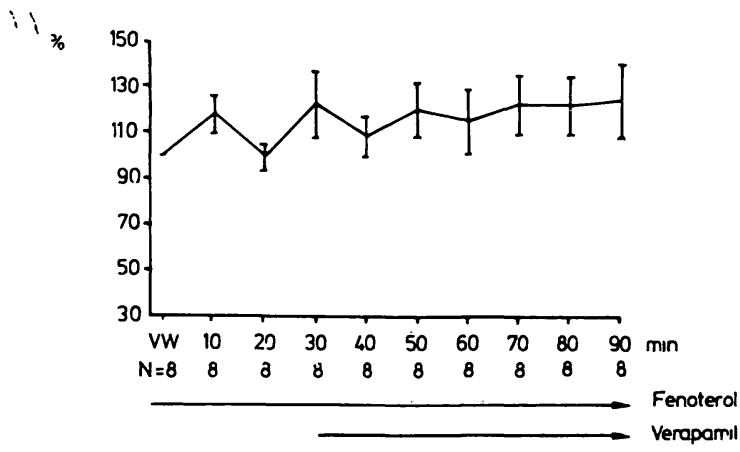

Fig. 6. Parameters of the pulmonary' circulatory system in dogs after administration of Fenoterol $(0.06 \mu \mathrm{g} / \mathrm{kg} / \mathrm{min})$ and subsequently of Verapamil $(2 \mu \mathrm{g} / \mathrm{kg} / \mathrm{min}) ; *=\mathrm{p}<0.05$, $* *=\mathrm{p}<0.01$.

pamil after previous administration of the betamimetic Fenoterol.

\section{Discussion}

The effectiveness and the mechanism underlying the effect of the calcium antagonist Verapamil are known and are indisputable. They have been demonstrated in numerous well-founded works, in part on isolated preparations and in part on animals as well as on sick and healthy people [11, $15,16,24,25,26,27]$. FlECKENSTEIN [12] revealed the mechanism of the cardiotoxic effect of adrenergics and the possibility of antagonizing this effect with Verapamil (Fig. 1).

As the prototype of beta-mimetics in earlier experiments, they used Isoproterenol. It has been shown that adrenergics lead to infarct-like lesions [33] with the clinical picture of catecholaminmyocarditis arising from hypoxia [4, 37]. These myocardial alterations, also found after an overdose of adrenergics and in pheochromocytoma [4], have gained importance in obstetrics ever since reports have been appearing in the past few years not only of serious pulmonary complications in the form of pulmonary edema $[1,2,5,8,13$, $20,39,43,45,46]$, but also of severe myocardial damage in tocolysis with various beta-sympathicomimetics $[2,6,7,31]$.

Also, infantile myocardiopathy after protracted tocolysis has been observed. A correlation between the therapy with beta-mimetics and the cardiac damage seems at least plausible [32, 40, 42]. Thus, interest became centered on the effects of the calcium-antagonist Verapamil administered in tocolysis. Whereas at first only an improvement of the subjective complaints after administration of beta-mimetics was hoped for, it is now the question of a demonstrable effect on the cardovascular system that raises interest. The pulmonary circulatory system must be included in these considerations.

The cardioprotective effect of Verapamil is associated with a negative inotropic and negative chronotropic effect. It is precisely these effects that have been least researched in tocolysis. In our experiments the contractility parameters and consequently also the myocardial oxygen requirement changed after administration of Fenoterol, as is to be expected from a beta-mimetic.

The contractility underwent an enormous increase as did the oxygen consumption, the end effect of which must be a deterioration of the energy balance. The administration of Verapamil at the dosage rate of $2 \mu \mathrm{g} / \mathrm{kg} / \mathrm{min}$ had no influence on this process. Thus a cardioprotective effect on the myocardium could not be proved.

That the mean arterial pressure continued to drop slightly after administration of Verapamil was chiefly due to the lowered diastolic pressure. Whether this effect is to be attributed to Feno- 
EXTRAVASCULAR FLUID VOLUME _ _ - -

INTRAVASCULAR BLOOD VOLUME

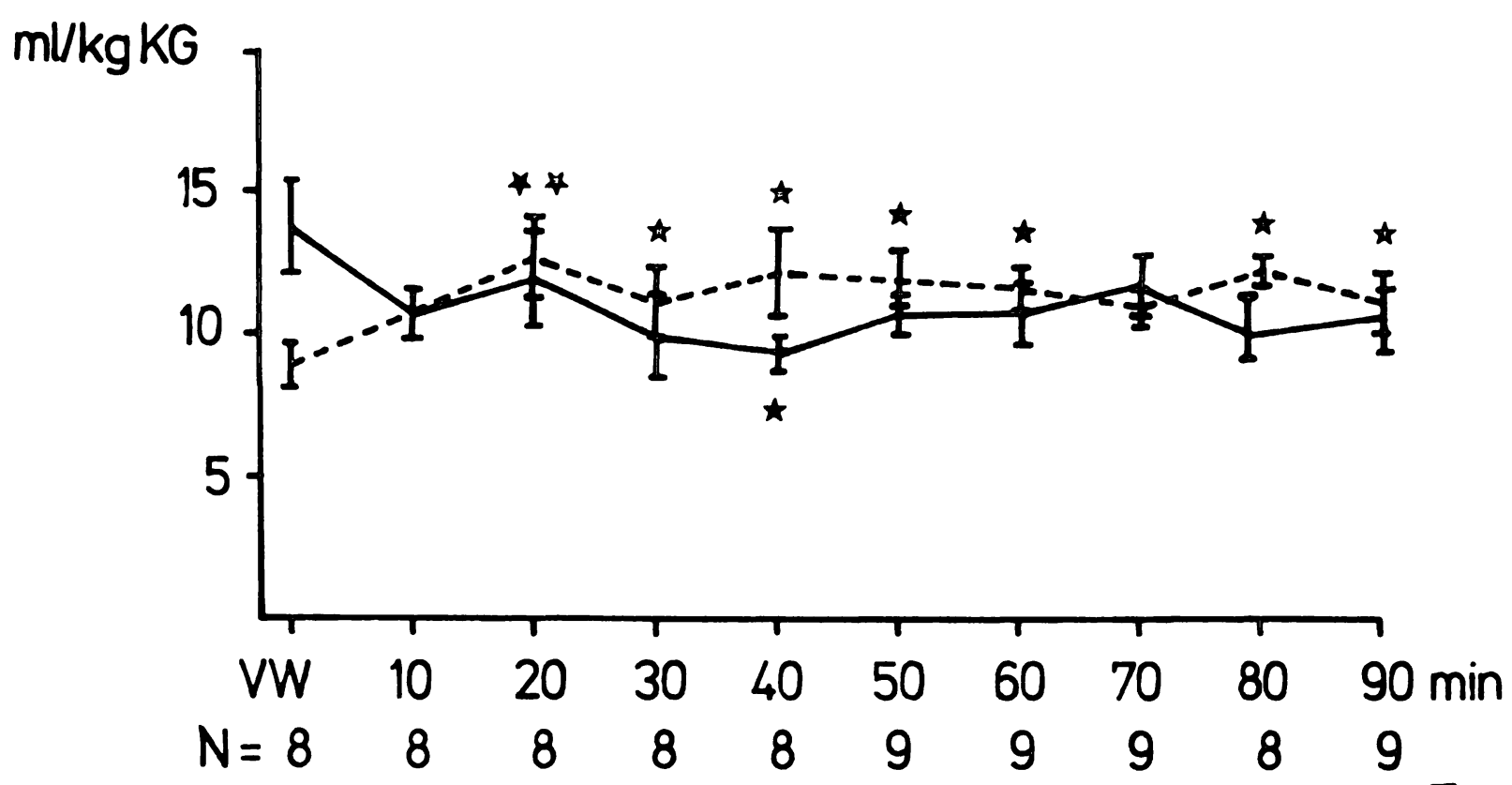

Fenoterol

Verapamil

Fig. 7a. Intrapulmonary fluid shifts in dogs after administration of Fenoterol $(0.06 \mu \mathrm{g} / \mathrm{kg} / \mathrm{min})$ and subsequently of Verapamil $(2 \mu \mathrm{g} / \mathrm{kg} / \mathrm{min}) ; *=\mathrm{p}<0.05, * *=\mathrm{p}<0.01$.

TOTAL INTRAPULMONARY FLUID VOLUME

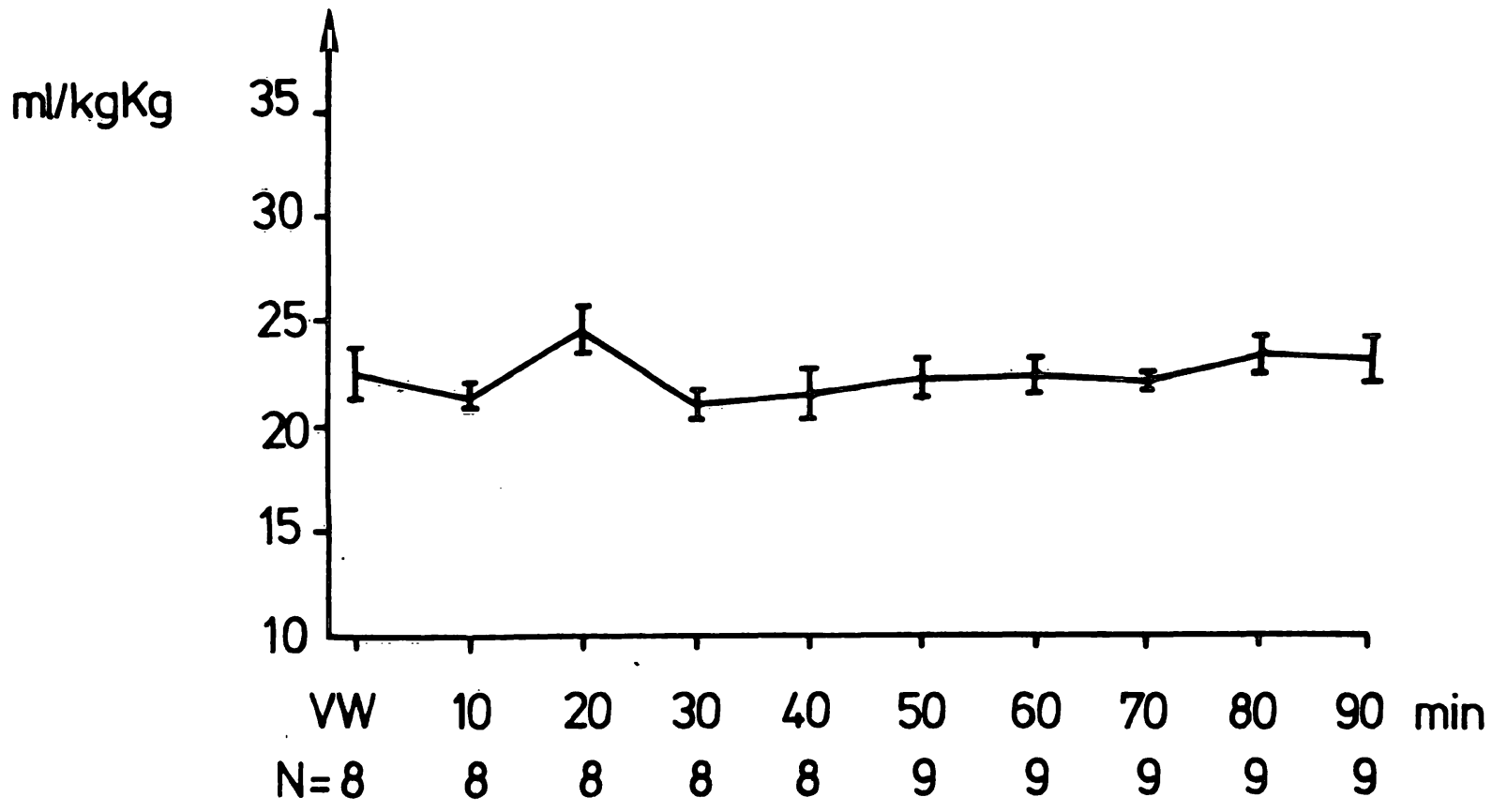

Fenoterol

Verapamil

Fig. 7b. Total intrapulmonary liquid balance in dogs after administration of Fenoterol $(0.06 \mu \mathrm{g} / \mathrm{kg} / \mathrm{min})$ and subsequently of Verapamil $(2 \mu \mathrm{g} / \mathrm{kg} / \mathrm{min})$. 


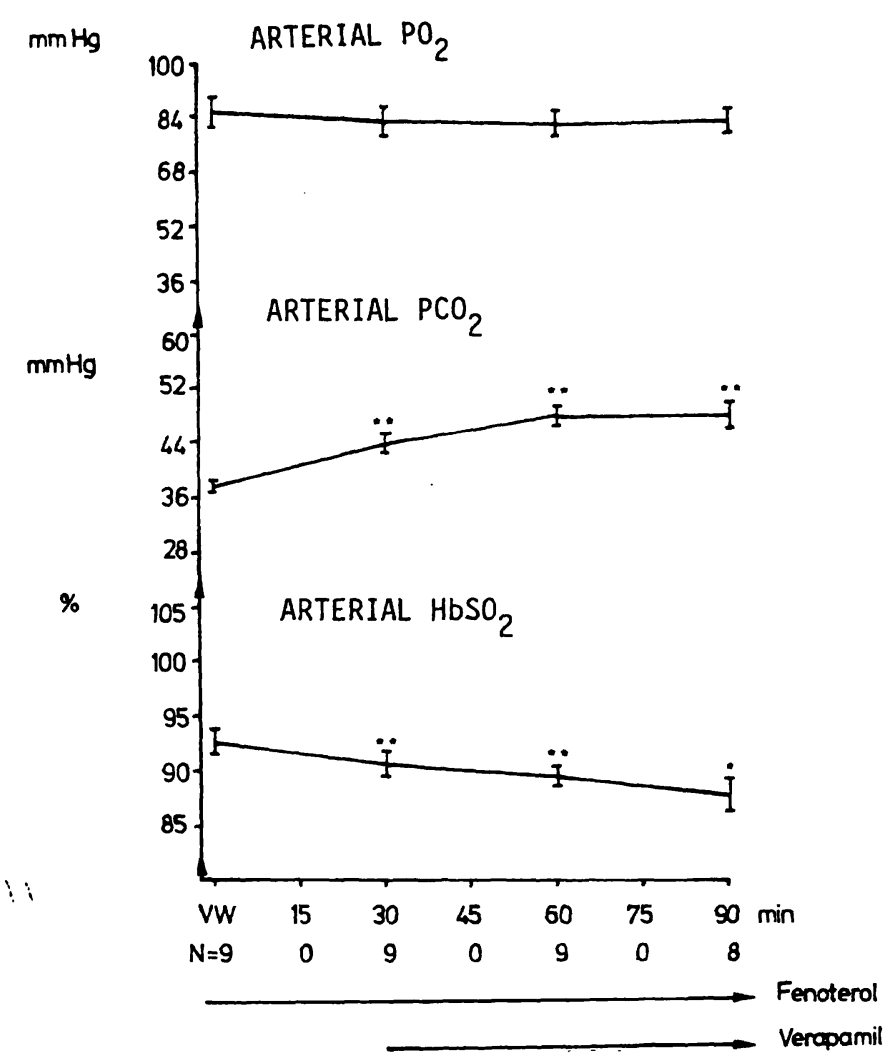

Fig. 8. Behaviour of arterial blood gases in dogs after administration of Fenoterol $(0.06 \mu \mathrm{g} / \mathrm{kg} / \mathrm{min})$ and subsequently of Verapamil $(2 \mu \mathrm{g} / \mathrm{kg} / \mathrm{min}) ; *=p<0.05$, $* *=\mathrm{p}<0.01$.

terol or to Verapamil cannot be stated. A Verapamil effect, however, seems unlikely, in view of the fact, that no other parameter of the systemic and pulmonary circulatory system underwent further change.

The metabolic acidosis known to occur after administration of Fenoterol [21, 41] was also encountered in our investigations. It reacted as little to the administration of Verapamil as did the changes in the ventilation and the blood gases.

The explanation for the ineffectiveness of the calcium antagonist Verapamil lies in the low dose of $2 \mu \mathrm{g} / \mathrm{kg} / \mathrm{min}$. The desired shift of the functional operating curves of the heart and the circulatory effect of Verapamil can only be achieved with doses far higher than those used in tocolysis. In these earlier studies an effect was demonstrated in dogs only after a dose of $200 \mu \mathrm{g} / \mathrm{kg} / \mathrm{min}$, given as a single injection, and in humans only after serum concentrations of $200 \mu \mathrm{g} / \mathrm{ml}$ were reached [11, 15, $16,24,25]$. HAAS and RASCHAK [16] also reported that in general extremely high doses of the cal-

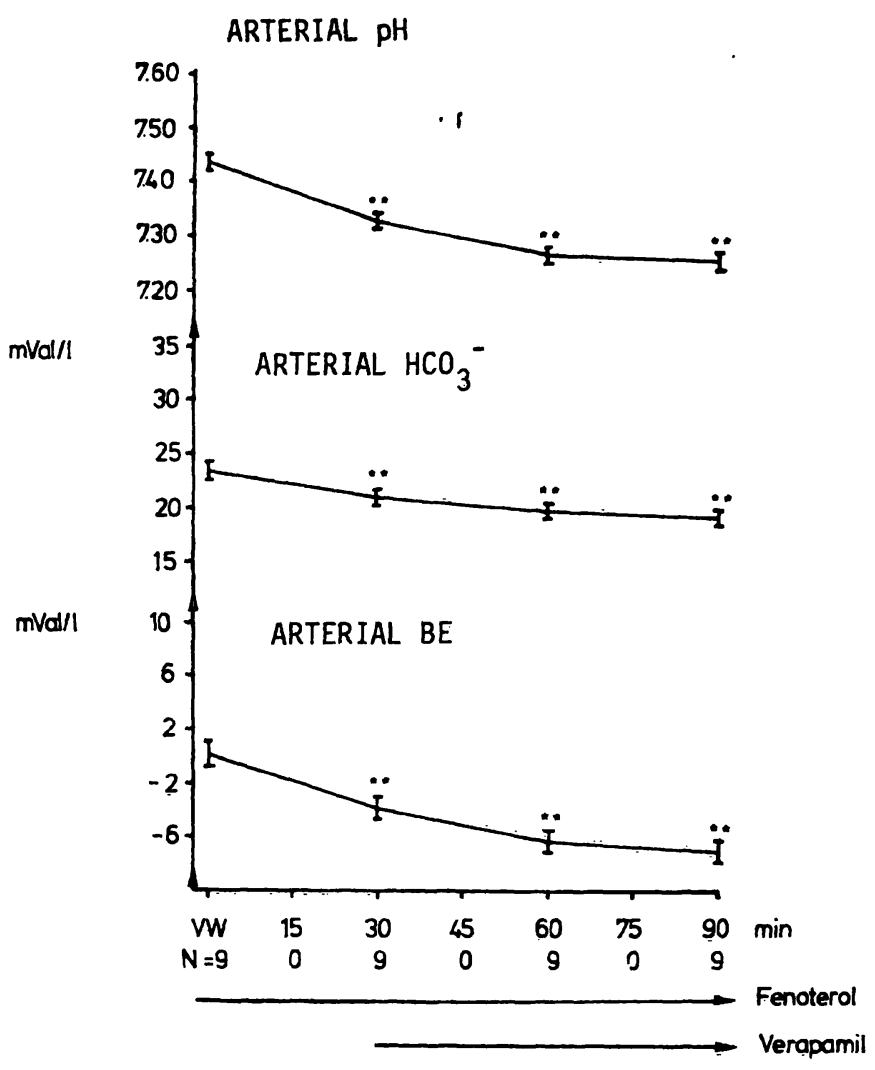

Fig. 9. Arterial acid-base-status in dogs after administration of Fenoterol $(0.06 \mu \mathrm{g} / \mathrm{kg} / \mathrm{min})$ and subsequently of Verapamil $(2 \mu \mathrm{g} / \mathrm{kg} / \mathrm{min}){ }^{*}=\mathrm{p}<0.05, * *=\mathrm{p}<0.01$.

cium antagonist are required to obtain the negative inotropic effect. The reason for this is the rapid biotransformation of the active substance Verapamil into ineffective or only weakly effective metabolites [34]. Our own studies [38] have revealed that the average serum concentration of the mother after administration of Verapamil at a dosage rate of $2 \mu \mathrm{g} / \mathrm{kg} / \mathrm{min}$ was $19.3 \pm 3 \mathrm{ng} / \mathrm{ml}$.

Since fluid displacements in the lungs up to the severity of manifest pulmonary edema after administration of adrenergics is due at least in part to hemodynamic factors $[3,10,36]$, it comes as no surprise that the administration of Verapamil has no influence on the fluid displacement from the intravascular to the extravascular space induced by Fenoterol.

In accordance with our findings, no change in the objective cardiovascular parameters in tocolysis with beta-mimetics attributable to the administration of Verapamil could be clinically established $[14,17,28,30]$. The researches had restricted themselves for the most part to measuring the 


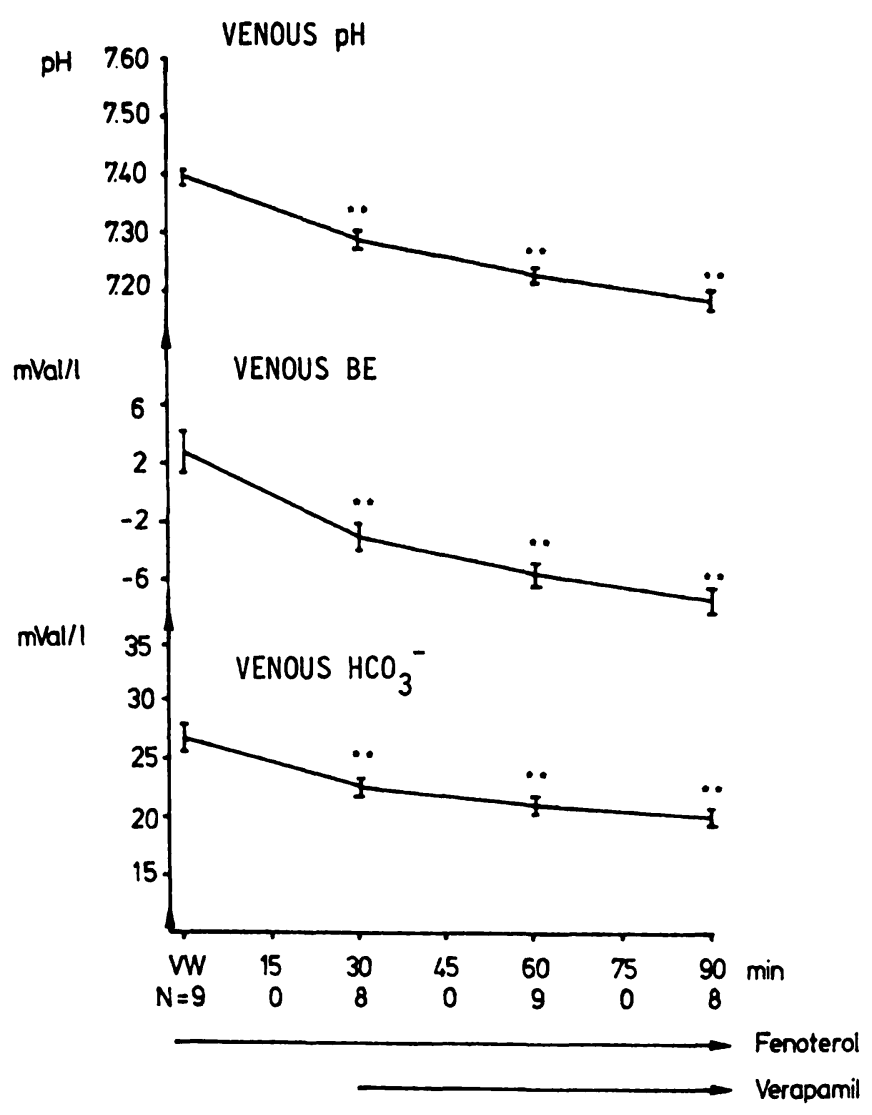

Fig. 10. Venous acid-base-balance in dogs after administration of Fenoterol $(0.06 \mu \mathrm{g} / \mathrm{kg} / \mathrm{min})$ and subsequently of Verapamil $(2 \mu \mathrm{g} / \mathrm{kg} / \mathrm{min}) ;^{*}=\mathrm{p}<0.05 ; * *=\mathrm{p}<0.01$.

parameters of the systemic circulatory system. In a recent study HofsTETTER [18] showed the ineffectiveness of the calcium antagonist in this dosage by using echocardiography to measure the inotropy. Objective improvements in the cardiovascular load achieved with Verapamil during tocolysis that have been determined with impedance measurements [35] must be viewed with scepticism owing to the inherent errors of the method. The elimination or manifest improvement of the side effects of beta-mimetics with Verapamil described by many authors are difficult to objectify.

The cardioprotective effect of Verapamil in a Fenoterol bath demonstrated in vitro [44] may result from the lack of metabolic decomposition and the resulting higher concentrations.

\section{Conclusions}

1. Fenoterol at a dosage rate of $0.06 \mu \mathrm{g} / \mathrm{kg} / \mathrm{min}$ induces in dogs the cardiovascular and metabolic

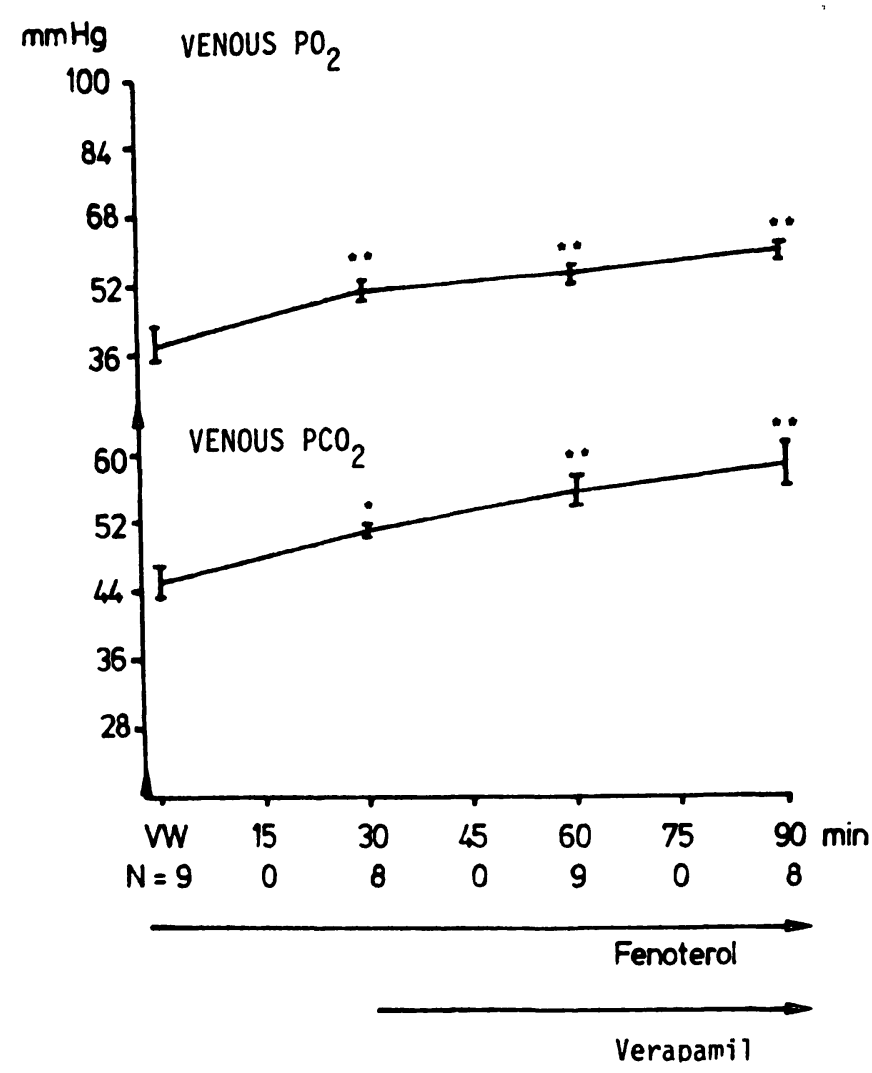

Fig. 11. Behaviour of venous blood gases in dogs after administration of Fenoterol $(0.06 \mu \mathrm{g} / \mathrm{kg} / \mathrm{min})$ and subsequently of Verapamil $(2 \mu \mathrm{g} / \mathrm{kg} / \mathrm{min}) ; *=\mathrm{p}<0.05$, $* *=\mathrm{p}<0.01$.

changes expected from the beta-sympathicomimetic. Besides this it causes significant intrapulmonary fluid shifts from the intravascular space to the interstice.

2. Verapamil in the dosage usual in clinical tocolysis of $2 \mu \mathrm{g} / \mathrm{kg} / \mathrm{min}$ has no influence on the changes induced by the beta-mimetic drug which are demonstrated in the present work. These results agree well with previous clinical experiments.

3. In order to achieve an effect the Verapamil dosage must be increased multifold, which hardly seems feasible in view of the cardiodepression and peripheral dilatation this would entail.

4. Since beta-sympathicomometics in labor suppression cannot be dispensed with at this time, further investigations will be necessary to find a substance that antagonizes the cardiovascular side effects in a way that can be objectified. 


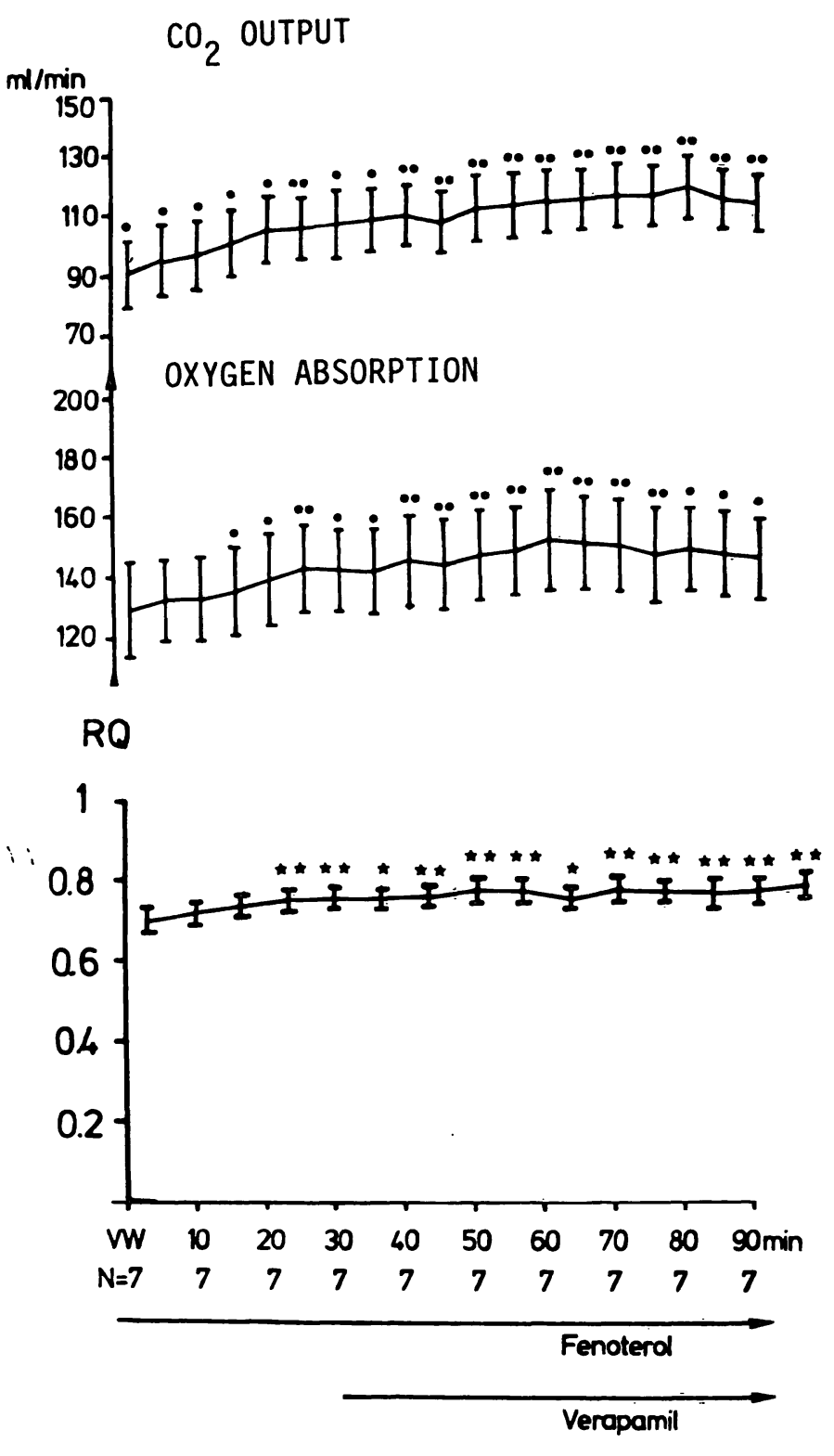

Fig. 12. Behaviour of the parameters of energy transformation in dogs after administration of Fenoterol $(0.06$ $\mu \mathrm{g} / \mathrm{kg} / \mathrm{min})$ and subsequently of Verapamil $(2 \mu \mathrm{g} / \mathrm{kg} / \mathrm{min})$; $*=\mathrm{p}<0.05, * *=\mathrm{p}<0.01$.

\section{Summary}

In tocolysis with beta-sympathicomimetics Verapamil is administered universally to reduce the subjective and objective cardiovascular side effects. The efficacy of the calcium-antagonist has not yet been substantiated. This has now re-emerged as an important issue due to the increasing occurrance of cardiopulmonary complications in tocolysis, some fatal.
COLLOID OSMOTIC PRESSURE IN PLASMA
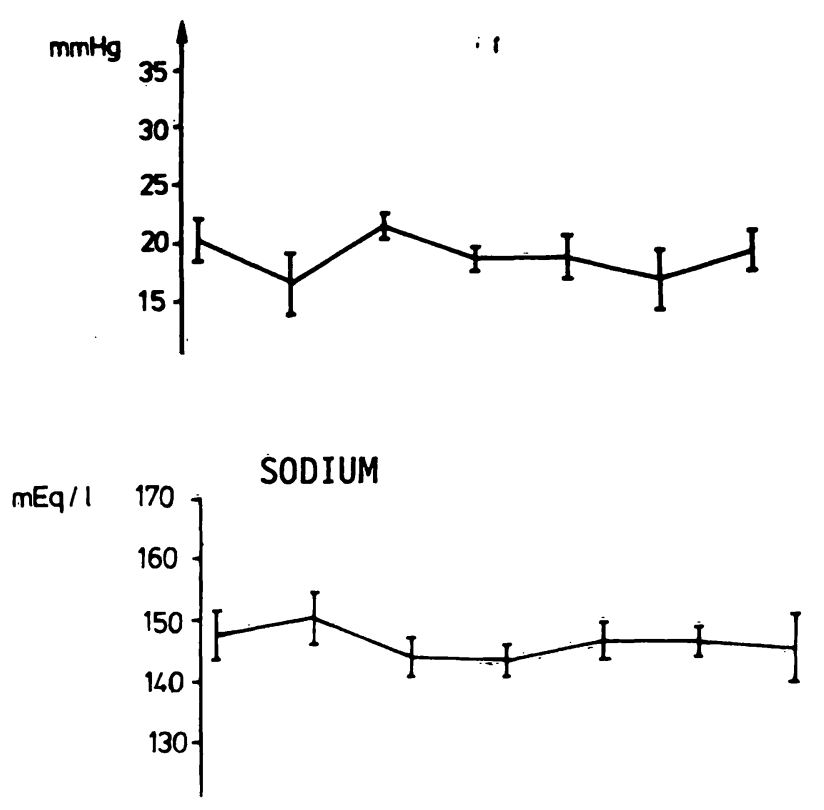

\section{POTASSIUM}

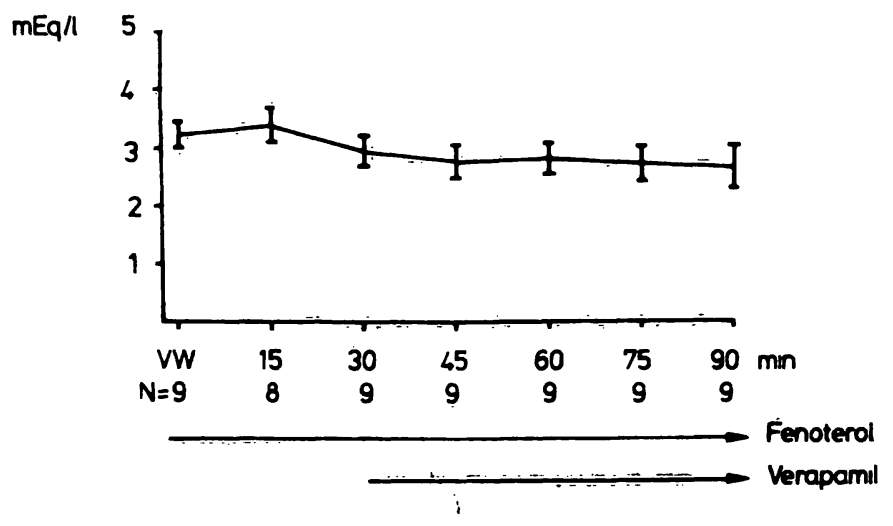

Fig. 13. Behaviour of the colloid osmotic pressure, plasma sodium and potassium in dogs after administration of Fenoterol $(0.06 \mu \mathrm{g} / \mathrm{kg} / \mathrm{min})$ and subsequently of Verapamil $(2 \mu \mathrm{g} / \mathrm{kg} / \mathrm{min})$.

Nine mongrel German shepherds were anesthetized and relaxed, and their breathing was controlled at constant volume. After infusion of Fenoterol $(0.06 \mu \mathrm{g} / \mathrm{kg} / \mathrm{min})$ and subsequent administration of Verapamil $(2 \mu \mathrm{g} / \mathrm{kg} / \mathrm{min})$ a continuous record was made of the parameters of the pulmonary and systemic circulatory systems, the cardiac dynamics, the acid-base balance, the blood gases.with $\mathrm{O}_{2}$ absorp- 
tion and $\mathrm{CO}_{2}$ output, electrolytes and the colloid osmotic pressure. Furthermore, the intrapulmonary fluid volumes in the vascular system and the interstice were measured.

During infusion with Fenoterol the changes expected from a beta-adrenergic were observed in the form of a hyperkinetic cardiac situation, metabolic acidosis and increased exchange of gases. Also pronounced fluid shifts in the lungs occurred from the intravascular space to the interstice.

Subsequent administration of the calcium antagonist showed no influence on the beta-mimetic-induced changes demonstrated in the present work.
The results agree with previous clinical investigations. According to the known dosage curve, the dosage of Verapamil would have to be increased multifold to achieve an effect, which is hardly possible due to the cardiodepression and peripheral circulation drop with hypotension that this would entail.

The administration of Verapamil in tocolysis no longer appears expedient.

Keywords: Betamimetic drugs, calcium antagonists, myocardiopathy, pulmonary edema, tocolysis.

\section{Zusammenfassung}

Hat der Zusatz des Kalziumantagonisten Verapamil bei der Tokolyse mit Betasympathikomimetika noch einen Sinn?

Bei der Tokolyse mit Betasymathikomimetika wird zur Verringerung der subjektiven und objektiven kardiovaskulären Nebenwirkungen weltweit Verapamil zugesetzt. Die Wirksamkeit des Kalziumantagonisten ist bisher nicht gesichert. Ihr kommt jedoch nach immer häufiger auftretenden, teilweise letal verlaufenden kardiopulmonalen Zwischenfällen bei der Tokolyse wieder vermehrt Bedeutung $\mathrm{zu}$.

9 Bastardschäferhunde wurden narkotisiert, relaxiert und volumenkonstant kontrolliert beatmet. Nach Infusion von Fenoterol $(0.06 \mu \mathrm{g} / \mathrm{kg} / \mathrm{min})$ und späterem Zusatz von Verapamil ( $2 \mu \mathrm{g} / \mathrm{kg} / \mathrm{min}$ ) konnten laufend die Parameter des großen und kleinen Kreislaufs, der Herzdynamik, des Säure-Basen-Haushalts sowie die Blutgase mit $\mathrm{O}_{2}$-Aufnahme und $\mathrm{CO}_{2}$-Abgabe, Elektrolyte und der Kolloidosmotische Druck bestimmt werden. Außerdem wurden die intrapulmonaren Flüssigkeitsvolumina im Gefäßsystem und im Interstitium gemessen.

Während der Infusion von Fenoterol zeigten sich die für ein Betaadrenergikum zu erwartenden Veränderungen im Sinne einer hyperkinetischen kardialen Situation, eine metabolische Azidose und ein verstärkter Gasaustausch. Weiter kam es zu einer deutlichen Flüssigkeitsverschiebung in der Lunge vom intravasalen Raum zum Interstitium. Der spätere Zusatz des Kalziumantagonisten zeigte keinen Einfluß auf die in dieser Arbeit nachgewiesenen, durch das Betamimetikum bedingten Veränderungen.

Die Ergebnisse entsprechen den bisherigen klinischen Untersuchungen. Nach den bekannten Dosisleistungskurven müßte zum Erreichen einer Wirkung die Dosis von Verapamil auf ein Vielfaches erhöht werden. Dies ist wegen der zu erwartenden kardialen Depression und dem peripheren Kreislaufabfall mit Hypotension schlecht möglich. Der Zusatz von Verapamil bei der Tokolyse mit Betasympathikomimetika erscheint nicht mehr sinnvoll.

Schlïsselwörter: Betamimetika, Kalziumantagonisten, Kardiomyopathie, Lungenödem, Tokolyse.

\section{Résumé}

L'administration de Verapamil, antagoniste du calcium, lors de la tocolyse par les bétamimétiques, garde-t-elle encore une signification.

Lors de la tocolyse par béta-mimétiques, tout le monde administre du Vérapamil afin de réduire les effets secondaires cardio-vasculaires subjectifs et objectifs. L'efficacité de cet antagoniste du calcium n'a cependant pas été établie.

Ce point resurgit maintenant de façon aigue à cause de la survenue croissante de complications cardio-pulmonaires, dont quelques unes fatales, au cours de la tocolyse.

9 bergers-allemands batards ont été anesthésiés et leur respiration a été contrôlée à volume constant. Après perfusion de Fénoterol $(0,06 \mu \mathrm{g} / \mathrm{Kg} / \mathrm{min})$ et administration secondaire de Vérapamil $(2 \mu \mathrm{g} / \mathrm{Kg} / \mathrm{min})$, un enregistrement continue a étế réalisé des paramètres des système circula- toires pulmonaires et systématiques, de la dynamique cardiaque, de l'équilibre acido-basique, des gaz du sang avec la consommation d'O $\mathrm{O}_{2}$ et l'élimination de $\mathrm{CO}_{2}$, des électrolytes et de la pression osmotique. En outre, les volumes liquides intra-pulmonaires dans le système vasculaire et dans l'espace interstitiel ont été mesurés.

Pendant la perfusion de Fenotérol, on a observé les modifications attendues d'un béta-adrénergique sous l'aspect d'une activité cardiaque hypercinétique, d'une acidose métabolique et d'échanges gazeux augmentés. Se produisirent également des modifications liquidiennes importantes de l'espace intravasculaire vers l'espace interstitiel pulmonaire. L'administration secondaire de l'antagoniste du calcium n'a pas montré d'influence démontrée dans ce travail sur les modifications induites par les béta-mimétiques. 
Les résultats concordent avec les explorations cliniques antérieures. Selon la cinétique du dosage habituel, la posologie du Vérapamil devrait être augmentée plusieurs fois pour exercer une action, ce qui est difficilement possible du fait de la dépression cardiaque et de la diminution de la circulation périphérique avec hypotension que cela entraînerait.

L'administration de Vérapamị lors de la tocolyse avec bétamimétiques n'apparait plus comme opportune.

Mots-clés: Antagonistes du calcium, bétamimétiques, myocardiopathie, oedème pulmonaire, tocolyse.

\section{Bibliography}

[1] BABENERD, I., I. FLEHR: Mütterliche Zwischenfälle unter der Tokolyse mit Fenoterol. Med. Welt, 30 (1979) 537

[2] BENDER, H. G., G. GOECKENJAHN, CH. MEGER, M. MÜNTEFERING: Zum mütterlichen Risisko der medikamentösen Tokolyse mit Fenoterol (Partusisten ${ }^{\circledR}$ ). Geburtsh. u. Frauenheilk. 37 (1977) 665

[3] BERK, I. L., I. F. HAGEN, R. KOO, W. BEYER, G. R. DOCHAT, M. RUPRIGHT, S. NOMOTO: Pulmonary insufficiency caused by epinephrine. Ann. Surg. 178 (1973) 423

[4] BERSCH, W., F. BÜHLER: Pathologische Anatomie der sogenannten Epinephrin-Myokarditis beim Menschen. In: SEIFERT, G. (Ed.): Verhandlungen der Deutschen Gesellschaft für Pathologie. Fischer, Stuttgart 1972

[5] CONRADT, A., H. WEIDINGER, W. WIEST:Schweres Lungenödem unter Tokolyse: Entdeckung causaler Faktoren durch ein „Präventions-Programm". Arch. of Gynecol. Vol. 228, 42. Gynäkologenbericht Springer, Berlin-Heidelberg-New York 1979

[6] DAUBERT, J. C., P. GOSSE, M. RIO, J. Y. GRALL, C. BOURDONNEC, J. C. PONY, J. GOUFFAULT: Myocardiopathies en cours de grossesse. Rôle possible des betamimétiques. Arch. mal cœur, 71, 11 (1978) 1283

[7] DHAINAUT, J. F., G. BOUTONNET, S. WEBER, M. DEGEORGES: Responsabilité des betamimétiques prescrits au cours de la grossesse dans la genèse d'une cardiomyopathie du post-partum. Nouv. presse med. 7, 44 (1978) 4058

[8] ElliotT, M. R., U. ABDULLA: Pulmonary oedema associated with ritodrine infusion and betamethasone administration in premature labour. Brit. Med. J. (1978) 799

[9] ENGELHARDT, A.: Myokardnekrosen nach Adrenergika - Diskussionsbeitrag - Int. J. Clin. Pharmacol. Beiheft 4

[10] ERSOZ, N., S. C. FINESTONE: Adrenaline-induced pulmonary oedema and its treatment. A report of two cases. Brit. J. Anaesth. 43 (1971) 709

[11] FLECKENSTEIN, A., M. KAMMERMEIER, H. J. DÖRING, M. J. FREUND: Zum Wirkungsmechanismus neuartiger Koronardilatatoren mit gleichzeitig Sauerstoff-einsparenden Myokardeffekten, Prenylanin und Iproveratril. Z. f. Kreislaufforsch. 56 (1967) 716,839

[12] FLECKENSTEIN, A., J. JANKE, G. FLECKENSTEIN-G-RƯN: Kardiotoxische Wirkungen beta- adrenerger Tokolytika-Kardioprotektion durch $\mathrm{Ca}^{++}$ Antagonisten. In: HILLEMANNS, H.G., R. TROLP (Eds.): Kardiale Probleme bei der Tokolyse. Enke, Stuttgart 1978

[13] GROSPIETSCH, G., J. GIRUDT, M. FENSKE, W. KÜHN: Zur Frage des Lungenödems bei der tokolytischen Therapie. Geburtsh. u. Frauenheilk. 40 (1980) 55

[14] GUMMERUS, M.: Die Behandlung der vorzeitigen Wehentätigkeit und Antagonisierung der Nebenwirkungen der tokolytischen Therapie mit Verapamil. Z. Geburtsh. u. Perinat. 181 (1977) 334

[15] HAAS, M., G. HÄRTFELDER: $\alpha$-Isopropyl- $\alpha-$ [(N-methyl-N-homoveratryl)- -aminopropyl]-3,4-dimethoxyphenylacetonitril, eine Substanz mit coronargefäßerweiternden Eigenschaften. Arzneim. Forsch. 12 (1962) 549

[16] HAAS, M., M. RASCHAK: Verapamil (Isoptin ${ }^{\circledR}$ ), ein Therapeutikum mit antiarrhythmischer Wirkung. Herz-Kreisl. 5 (1973) 416

[17] HILTMANN, W. D., H. WEIDINGER: Subjective und objective Cardiovascular sideeffects and their antagonising during clinical treatment with betamimetics. In: WEIDINGER, H. (ed.): Labour Inhibition. Fischer, Stuttgart-New York 1977

[18] HOFSTETTER, R., H. G. SCHMIDT, W. KREBS, D. LANG, G. V. BERNUTH: Kardiale Wirkung von Fenoterol allein oder in Kombination mit Verapamil. Z. Geburtsh. Perinat. 183 (1979) 335

[19] HOLCROFT, J. W., D. D. TRUNKEY, M. A. CARPENTER: Excessive fluid administration for resuscitating baboons from hemorrhagic shock and an assessment of the thermodyetechnic for measuring extravascular lung water. Amer. J. Surg. 135 (1978) 412

[20] JONATHA, W., L. GOESSENS, E. TRAUB, W. DICK: Pulmonale Komplikationen während der Tokolyse. In: JUNG, H., E. FRIEDRICH (eds.): Fenoterol (Partustisten ${ }^{\circledR}$ ) bei der Behandlung in der Geburtshilfe und Perinatologie. Thieme, Stuttgart 1978

[21] KLÖCK, F. K., H. CHANTRAINE, A. ETZRODT, B. LIEDKE, H. J. SCHULTE: Der Einfluß des Beta-Stimulators Th 1165 a auf mütterliche und fetale Stoffwechselparameter. In: DUDENHAUSEN, J. W., E. SALING (eds.): Perinatale Medizin, IV. Thieme, Stuttgart 1973

[22] LEWIS, F. R., V. I. ELINGS: Microprocessor determination of lung water using thermal green dye double indicator dilution. Surg. Forum 29 (1978) 182 
[23] LEWIS, F. R., V. I. ELINGS, I. A. STURM: Bedside measurement of lung water. J. Surg. Res. 27 (1979) 250

[24] MEL VILLE, K. I., H. L. GARVEY, H. E. SHISTER: On the cardiac adrenergic blocking action of iproveratril in normal and coronary-ligated dogs. Rev. Can. Biol. 27 (1968) 225

[25] NAYLER, W. G., I. MC. INNES, J. B. SWANN, J. M. PRICE, V. CARSON, D. RACE, T. E. LOWE: Some effects of Iproveratril (Isoptin) on the cardiovascular system. J. Pharmacol. and Exp. Therap. 161 (1968) 247

[26] NAYLER, W. G., J. SZETO: Effect of verapamil on contractility, oxygen utilization and calcium exchangeability in mammalian heart muscle. Cardiovasc. Res. 6 (1972) 120

[27] NAYLER, W. G., A. GRAU, A. SHADE: A protective effect of Verapamil on hypoxic heart muscle. Card. Vasc. Res. 10 (1976) 650

[28] NEUBUSER, D.: Clinical comparison of buphenine, TV 399, Partusisten ${ }^{\circledR}$ and Verapamil. In: WEIDINGER, H. (ed.): Labour Inhibition. Fischer, Stuttgart-New York 1977

[29] PFEIFFER, U., M. BIRK, G. ASCHENBRENNER u. G. BLUMEL: The system for quantitating thermaldye extravascular lung water. In: NAIR, S. (ed.): Computers in critical care and pulmonary medicine Plenum New York 1980

[30] RICHTER, R., M. J. HINSELMANN: The treatment of threatened premature labour by betamimetic drugs: a comparison of Fenoterol and Ritodrine. Obstet. and Gynaec. 53, 1 (1979) 81

[31] RIES, G. H. : Kasuistische Mitteilung über das Auftreten einer Myokardischämie unter medikamentöser Tokolyse mit Ritodrin (PRE-PAR) Geburtsh. $u$. Frauenheilk. 39, 1 (1979) 33

[32] ROBRECHT, D., H. G. HILLEMANNS, W. WEICHSEL, H. STEINER: Notfall - Cerclage. Geburtsh. u. Frauenheilk. 39 (1979) 869

[33] RONA, G., C. I. CHAPPEL, T. BALAZS, R. GOUDRY: An infarct-like myocardial lesion and other toxic manifestations produced by Isoproterenol in rat. Arch. Path. 67 (1959) 443

[34] SCHOMERUS, M., B. SPIEGELHALDER, B. STIEREN, M. EICHELBAUM: Physiological disposition of Verapamil in man. Cardiovasc. Res. 10(1976) 605

[35] SCHUMANN, R., E. HALBERSTADT, R. SERNER, R. RAAB: Änderungen von Kreislaufparametern unter tokolytischer Behandlung. In: JUNG, H., E. FRIEDRICH (eds.): Fenoterol (Partusisten ${ }^{\circledR}$ ) bei der Behandlung in der Geburtshilfe und Perinatologie. Thieme, Stuttgart 1977

[36] STAUB, N. C.: Pulmonary edema due to increased microvascular permeability to fluid and protein. Circ. Res. 43 (1978) 143
[37] STÖTZER, H.: Experimentelle-toxikologische Erfahrungen mit Partusisten ${ }^{\circledR}$ (Fenoterol), Orciprenalin. In: HILLEMANNS, H. G., R. TROLP: (eds.): Kardiale Probleme bei der Tokolyse. Enke, Stuttgart 1978

[38] STRIgL, R., G. GASTROPH, H. G. HEGE, P. DÖRING, W. MEHRING: Nachweis von Verapamil im muitterlichen und fetalen Blut des Menschen. Z. Geburtsh. u. Frauenheilk. 40 (1980) 496

[39] STUBBLEFIELD, P. G.: Pulmonary edema occuring after therapy with dexamethasone and terbuthaline for premature labor. A Case Report. Amer. J. Obstet. Gynec. 132 (1978) 341

[40] TROLP, R., H. P. HAASTERT, N. BÖHM, K. ULLRICH: Falldemonstration von drei Fällen mit pathologischen Erscheinungen am Herzen bei Kindern nach Tokolyse. In: HILLEMANNS, H.G., R.TROLP (eds.): Kardiale Probleme bei der Tokolyse. Enke, Stuttgart 1978

[41] UNBEhAUN, V., A. CONRADT, C. M. SCHLOTTER, V. SCHNEIDER: Stoffwechselveränderungen während Infusion von Th 1165 a. Z. Geburtsh. Perinat. 178 (1974) 118

[42] URBANEK, R., B. SCHMIDT-REDEMANN, W. PRINGSHEIM, H. P. HAASTERT, J. VOGT: Myokardveränderung nach Tokolyse. Wschr. Kinderheilk. 126 (1978) 340

[43] WEITZEL, H., D. BENTHIN, W. BURKERT, K. GLEIBE, H. J. MITZKAT: Komplikationen nach Celestangabe bei diabetischen Schwangeren. In: SCHMIDT, E., J. W. DUDENHAUSEN, E. SALING (eds.): Perinatale Medizin, IX. Thieme, Stuttgart 1981

[44] WIEST, W., H. WEIDINGER, A. SCHLEICH, W. HOFFMANN, D. SCHRÖTER: Der Einfluß von Betasympathikomimetika und sogeannter Calciumantagonistischer Hemmstoffe auf den menschlichen fetalen Herzmuskel. In: SCHMIDT, E., J. W. DUDENHAUsen, E. SALING (eds.): Perinatale Medizin, VII. Thieme, Stuttgart 1978

[45] WOLFF, F., U. MEIER: Untersuchungen schwerer kardiopulmonaler Komplikationen unter wehenhemmender Behandlung. In: SCHMIDT, E., J. W. DUdenhausen, E. SAling (eds.): Perinatale Medizin, IX. Thieme, Stuttgart 1981

[46] ZAHN, V., R. HALBRITTER, W. JONATHA: Aktuelle Probleme der Tokolytischen Therapie. In Press

Received May 9, 1980. Revised July 28, 1980. Accepted February 9, 1981.
Priv.-Doz. Dr. med. Rüdiger Strigl Frauenklinik der TU München Ismaninger Str. 22 D-8000 München 80 